\title{
Morphological change and the influence of language contacts in Estonian
}

\section{Grünthal, Riho}

University Press of Southern Denmark 2007

Grünthal , R 2007 , Morphological change and the influence of language contacts in Estonian . in Beiträge zur morphologie : Germanisch, Baltisch, Ostseefinnisch . University Press of Southern Denmark, Odense , pp. 403-432.

http://hdl.handle.net/10138/328462

acceptedVersion

Downloaded from Helda, University of Helsinki institutional repository.

This is an electronic reprint of the original article.

This reprint may differ from the original in pagination and typographic detail.

Please cite the original version. 


\section{Riho Grünthal}

\section{MORPHOLOGICAL CHANGE AND THE INFLUENCE OF LANGUAGE CONTACTS IN ESTONIAN}

Estonian is an illustrative example of a modern language that was intensively influenced by morphological attrition and foreign interfernce during the last millennium. The most salient typological differences of Estonian with respect to northern Finnic languages such as Finnish, Karelian and Veps are based on the loss of several important suffixes, in particular those of certain grammatical cases. This article discusses the interliaison of morphological and contact-induced change in the evidence of Estonian inflectional case system, case syncretism and certain adverbial constructions.

The main hypothesis is that diachronic changes often do not happen independently of one another and endogenous and contact-induced changes in Estonian affect the same functional domains. The conclusions of this article are mainly based on language-specific analysis and most of the data is drawn from Estonian. Nevertheless, there are certain parallels between case syncretism in Estonian, Vote and South-West Finnish dialects that will be used for comparative evidence. Convergent changes suggest that a particular morphological change does not inevitably have identical consequences even in genetically closely related languages.

Historically, Estonian forms the southern group of the Finnic languages with Livonian and Vote (Votian) that all share some important morphological changes such as the loss of the genitive(-accusative) $-n$. In Estonian, this change took place in the $15^{\text {th }}$ and $16^{\text {th }}$ century (Kingisepp $\&$ al. 1997:87-89). Compared to northern Finnic languages (Finnish, Karelian, Veps, Ingrian) the language contact area of Estonian is different, because it was more intensively influenced by German (and Low German) than any other Finnic language. The period of contacts with German lasted from $13^{\text {th }}$ to $20^{\text {th }}$ century and had a strong impact on Estonian. While Russian loanwords were borrowed from the east and are most numerous in the southern- and eastern-most Estonian dialects (Koponen 1998:224, Must 2000, Mägiste 1962), loans from German form the largest group of borrowings from western Indo-European languages. 


\section{RIHO GRÜNTHAL}

The German influence is not limited on certain dialects only, because it had special importance in the development of Estonian literary language particularly in its earliest stages. The long contacts between Estonian and German are evidenced by numerous lexical borrowings and it has repeatedly been assumed that the contacts led to certain syntactic parallels as well (Habicht 2000, Hasselblatt 1990, Hennoste 1997, Hinderling 1981, Laanekask\&Erelt 2003:280-310, Pajusalu 2000b).

Typologically, the changes in Estonian morphology increased the importance and frequency of flexive forms. This characteristic separates

10 Estonian and Livonian from other Finnic languages (Viitso 1998, 2000). Flexion and morphophonological alternation affect grammatical cases most strongly, while more generally speaking, Estonian morphology is predominantly suffixal. The adverbial cases display a consistent suffixal case system in all declension types. Consequently, the language should not be labeled flexive as a whole but rather, a language with mixed morphological strategies (Ehala 1997, Grünthal 2000, Plank 1998, 1999, Skalička 1975, Tauli 1984, Viitso 1990, 2003). Accordingly, morphological change should be understood as a mixture of different processes as well (Heine \& Kuteva 2005:123-171, Werner 1987). Yet, it must be noted that the reduction of suffixal morphology and word-based distinction between grammatical cases has considerably influenced Estonian noun declension and inflected words actually function as lexical constructions (Blevins 2004, 2005).

The different morphological strategies in Estonian case inflection are important for the goals of the current article as well, because the same cases

25 that display flexive morphology are also affected by syncretism and inflectional homonymy. The following aims at examining the consequences of morphological change and the historical background will be intertwined only, if it will shed additional light on the relationship between various changes.

\section{Morphological change in Estonian}

Given the different inflectional strategies in Estonian case morphology, the influence of morphological changes is bicuspid. Stem alternation was considerably reduced in adverbial cases that exhibit only little allomorphism, whereas grammatical cases display flexive morphology, complicated morphophonological alternation and allomorphism that is lexically ruled. In certain frequent 


\section{MORPHOLOGICAL CHANGE AND THE INFLUENCE OF LANGUAGE CONTACTS IN ESTONIAN}

bisyllabic noun stems the complexity is increased by lucrative case syncretism that will be examined in more detailed below. Blevins (2005:2) claims that from the viewpoint of theoretical morphology and word and paradigm (WP) models the way redundancy and fusion are manifested in Estonian noun declension suggests that they actually are symptoms of morphological 'overextraction'. This inevitably leads to a wide-spread mismatch between 'units of form' and 'units of content' in that there is no obvious rule according to which form and function would correspond to one another. As mentioned, this claim affects most intensively the three grammatical cases as shown in table 1 .

\begin{tabular}{|c||c|c||c|c|}
\hline & SINGULAR & PLURAL & SINGULAR & PLURAL \\
\hline \hline & 'son' & & 'window' & \\
\hline NOM & poeg & poja-d & aken & akna-d \\
\hline GEN & poja & poega-de & akna & aken-de \\
\hline PART & poega & $\begin{array}{c}\text { poeg-i } ~ \\
\text { poega-sid }\end{array}$ & akent & akna-id \\
\hline
\end{tabular}

Table 1. The inflection of grammatical cases in Standard Estonian.

Those morphological changes that have taken place in Estonian noun inflection influence especially the singular forms of the nominative (NOM), genitive-accusative (GEN) and partitive (PART) case, while suffixal forms play 15 a much bigger role in the distinction of plural forms (cf. table 1). Note that the genitive often occurs as the case of object and as such it historically originates from a (pre)historical accusative $*_{-} m$. The glossing GEN (in the glossed examples below GEN-ACC) refers to all morphosyntactic properties of the genitive-accusative including the case of possessor-marking genitive attribute and accusative object.

The intensive reduction of the three grammatical cases is crucial for the grammatical system, because all three are cases of nominal core arguments, subject and object, or functionally closely connected to them. The adverbial cases, in turn, were influenced to a certain extent by semantic change. As table

252 demonstrates, the genitive stem in the singular and the genitive form in the plural is systematically the stem to which adverbial case suffixes are attached, and they display consistently the morpheme order stem + number + case in the plural. 


\section{RIHO GRÜNTHAL}

\begin{tabular}{|c||c|c||c|c|}
\hline & SINGULAR & PLURAL & SINGULAR & PLURAL \\
\hline \hline & 'son' & & 'window' & \\
\hline ILL & poega & poega-de-sse & akna-sse & aken-de-sse \\
\hline INESS & poja-s & poega-de-s & akna-s & aken-de-s \\
\hline ELAT & poja-st & poega-de-st & akna-st & aken-de-st \\
\hline ALL & poja-le & poega-de-le & akna-le & aken-de-le \\
\hline ADESS & poja-l & poega-de-l & akna-l & aken-de-l \\
\hline ABL & poja-lt & poega-de-lt & akna-lt & aken-de-lt \\
\hline TERM & poja-ni & poega-de-ni & akna-ni & aken-de-ni \\
\hline TRANSL & poja-ks & poega-de-ks & akna-ks & aken-de-ks \\
\hline ESS & poja-na & poega-de-na & akna-na & aken-de-na \\
\hline COM & poja-ga & poega-de-ga & akna-ga & aken-de-ga \\
\hline ABESS & poja-ta & poega-de-ta & akna-ta & aken-de-ta \\
\hline
\end{tabular}

Table 2. The inflection of adverbial cases in Standard Estonian.

ILL $=$ illative, INESS $=$ inessive, ELAT $=$ elative, ALL $=$ allative, ADESS $=$ adessive, $\mathrm{ABL}=$ ablative, $\mathrm{TERM}=$ terminative, TRANSL $=$ translative, $\mathrm{ESS}=$ essive, $\mathrm{COM}=$ comitative, $\mathrm{ABESS}=$ abessive

Given that only the illative singular became closely involved in the continuum of morphological reduction and loss of suffixes the following analysis is mainly limited to the grammatical cases. In comparison to the inflection of grammatical cases in table 1, the inflection of adverbial cases in Standard Estonian is predictable on the basis of the given category, while the inflection of grammatical cases is not predictable on the basis of the case at issue. In other words, the grammatical cases display flexive morphology while adverbial cases display agglutinative morphology. Note that also plural partitive forms of certain word types such as jalg foot-NOM: jala foot-GEN: jalga foot.PART: jala-d foot-PL(NOM): jalga-de foot-PL.GEN: jalgu foot.PL.PART are flexive. This phenomenon is wide-spread in Estonian dialects as well and has caused the diffusion of analogical plural partitive forms (Alvre 1964, 1989, Laakso 1998, 2000:117-120, Pajusalu 2000a).

20 Thus, several morphological changes can be pointed out in Estonian case system that demonstrate very different changes in one particular language. The genitive, for instance is functionally a fusional case because it integrates the form of the possessor and object. So, complicated lexically based morphological rules increase the complexity of language. There is ample evidence on 
on-going morphological and syntactic changes in modern Estonian (Ehala 1997, Erelt\&Metslang 1997). The decrease of allomorphism and productivity of partitive suffixes - $t$ in the singular and -sid in the plural, for instance, demonstrate a tendency to morphological simplification by means of analogical forms.

Historically, the following conclusions can be drawn on the development of Estonian case inflection

- Flexive forms replaced certain suffixal forms. The rules of flexive forms are based on lexical, not on morphological information.

- The reduction of suffixal and other word-final elements caused case syncretism. In certain lexical types it may result in the merger between the case of subject and object.

- Instead of decreasing complexity the reduction of grammatical cases increased the cumulation of morphosyntactic information of flexive forms.

- The influence of analogy restricted the increase of allomorphy to some extent.

- The agglutinative morphology of adverbial cases increased consistency in morphology.

Diverse diachronic changes support the view that language change is not uniform even in one particular language. The development of Estonian case system suggests that certain changes are morphologically innovative, because 25 they considerably renovate the morphological mechanics, while other changes are preservative and reiterate existing ones (cf. Grünthal 2003:32-44). This kind of system in transition most obviously is likely to be sensitive to the influence of language contacts as well. As Heine and Kuteva (Heine\&Kuteva 2005:45-46) note, contact-induced new patterns do not emerge from nothing,

30 either, but often result from a long process in which an earlier pattern gives rise to a new one. Recent discussion on the development of phrasal verbs in the Uralic languages has emphasised the importance of both sides. In some languages such as Mansi, Khanty and Hungarian it appears that the rise of the category is endogenous (Honti 1999), while in the case of Estonian the development is somewhat different, because the obvious influence of German (Hasselblatt 2003). Laakso (2001) brings concrete examples on the interwining of endogenous and contact-induced change in Finnic. 


\section{RIHO GRÜNTHAL}

In the introduction of this article it was alleged that diachronic changes often do not happen independently of one another. In this section it was pointed out that as regards Estonian case system, the morphological erosion and typological change has affected most intensively the grammatical changes.

5 The rise of flexive morphology and increase of case syncretism presumably are a burden for grammatical functions and made the language more sensitive to grammatical restructuration. The following section discusses the overlapping of cases in inflectional paradigms and the syntactic context of Estonian case syncretism.

\section{Case syncretism in Estonian}

The most concrete consequence of syncretism is the blurring of the ideal oneto-one correspondence between form and function. In general, the overlapping of different forms may occur between mutually related and non-related morphological categories. Given that random identity between forms may exist in any language that has productive inflectional morphology, syncretic forms have been pointed out in numerous languages. Many Indo-European

20 languages, for instance, display some kind of inflectional homonymy (Carstairs 1984, 1987, Coleman 1976, Delbrück 1907, Johnston 1997, Luraghi 1987, Martínez 2001, Meiser 1992, Plank 1991). (A more comprehensive syncretism database can be found on the home page of Surrey morphological group (http://www.smg.surrey.ac.uk/Syncretism).)

25 Estonian case syncretism has special importance for the nominal core arguments of the clause, i.e. the subject and object. Livonian, one of the most closely related languages with Estonian, demonstrates a similar merger between the nominative and genitive as Estonian (Kettunen 1938:XXXVIIILI, Tveite 2004). However, the merger between the plural nominative and genitive is systematic in Livonian, whereas Estonian seems to be in a much more intensive state of transition. Unlike singular Estonian plural noun forms are only rarely involved with syncretism. Thus, the morphological realisation of the grammatical cases in singular and plural is divergent as in many IndoEuropean languages. Another difference between Estonian and Livonian is

35 that in Estonian syncretism affects three grammatical cases, i.e. the nominative, genitive(-accusative) and partitive, while in Livonian it is limited to the two first ones. 


\section{MORPHOLOGICAL CHANGE AND THE INFLUENCE OF LANGUAGE CONTACTS IN ESTONIAN}

According to morphological analyses on Standard Estonian vocabulary there are roughly 78,000 homonymous word forms in the basic vocabulary including both paradigmatic and non-paradigmatic homonymy. The vast majority, 57,000 cases (almost $75 \%$ of the data), represent paradigmatic identity in which two or more inflected forms of one word co-occur (Viks 1984, 1992, Erelt \& al. 1997:523-529). Inflectional homonymy is especially wide-spread in noun declension and case system that historically was more strongly influenced by the reduction of suffixal elements than verb conjugation.

10 The high number of homonymyous nominal case forms is caused by the fact that two-syllable stems are most frequent nouns. Table 3 demonstrates the inflection of six two-syllable nouns and the diverging linearity of syncretic forms. The nominative form of the sixth word siil 'hedgehog' consisted historically of two syllables (cf. Finnish siili id.) as most nouns that have a two-syllable inflectional stem. However, numerous one-syllable words that have a two-syllable inflectional stem such as kepp 'stick' : kepi stick.GEN : keppi stick.PART and hind 'price' : hinna price.GEN : hinda price.PART are not involved with syncretism, because of the loss of the final vowel and consonant gradation that causes the distinction between the three grammatical cases.

The lexical type at issue decides which cases are involved in the syncretism. The five combinations that are most common and cause the overlapping of paradigmatically adjacent singular forms are demonstrated in table 3 . Hence, the possible overlappings are nominative-genitive, nominativegenitive-partitive, nominative-partitive, genitive-partitive, and genitivepartitive-illative. It is important to recall here that the genitive is the case of possessor (attribute) and object (as genitive-accusative; see above).

\begin{tabular}{|c||c|c|c|c|c|}
\hline & 'year' & 'nest' & 'war' & 'name' & 'hedgehog' \\
\hline \hline NOM & aasta & pesa & sôda & nimi & siil \\
\hline GEN & aasta & pesa & sõja & nime & siili \\
\hline PART & aasta- $t$ & pesa & sõda & nime & siili \\
\hline ILL & aasta-sse & pessa & sôtta & nimme & siili \\
\hline
\end{tabular}

Table 3. The overlapping of syncretic case forms in Estonian.

Generally speaking, case syncretism is very frequent in Estonian and influences numerous nouns and those cases that display flexive forms. It therefore seems that flexion as an inflectional strategy is much less efficient in Estonian 


\section{RIHO GRÜNTHAL}

noun declension than agglutinative that unlike flexion does not leave any gaps in the case paradigm. The different diachronic background plays an important role, because agglutination also is a much more permanent strategy, while flexion and syncretism that often adds the morphosyntactic cumulation of individual flexive forms were caused by a relatively recent diachronic change.

Syncretism is repeatedly suggested as a possible explanation for morphological changes in Estonian and other Finno-Ugric languages. The partitive and illative, that are involved with syncretism, are involved with analogy as well. The plural partitive of nouns with a closed second-syllable vowel, such as nimi or kivi 'stone' is analogical nime-sid name-PL.PART, kivi-sid stonePL.PART instead of a another syncretic form nimi [SG.NOM] : *nimi [PL.PART] $(<* n i m i-(i-) t a ̈)$ or kivi [SG.NOM] : *kivi [PL.PART] $(<* k i v i-(i-) t a ̈)$. The analogical agglutinative illative form is possible of many albeit not all nouns that display a flexive illative form: pessa nest.ILL pesa-sse nest-ILL or nimme name.ILL nime-sse name-ILL (Kettunen 1962 (1929):92-93, 217). Recent loan words such as auto 'car' : auto-sse car-SG.ILL : auto-sid car-PL.PART apply the analogical forms as well, which demonstrates the productivity of the agglutinative strategy.

The hypothesis that syncretism is connected with other morphosyntactic changes and may trigger them under certain conditions is justified from the viewpoint of language structure. It is therefore necessary to examine the functional consequences of morphological overlappings in more detail. Tables 4.1, 4.2 and 4.3 present the inflection of three different declension types in Estonian and the distinction between inflectional forms and different functions. The tables include nouns that distinguish between the grammatical cases and flexive inflectional forms in three different ways. The first one vaene 'poor' (table 4.1) makes, partly by means of suffixes, a morphological distinction between all cases that in certain declension display flexive forms, i.e. the nominative, genitive, partitive and illative. The second one, kott 'bag' (table 4.2), distinguishes between the grammatical cases by means of flexive forms, while the third one, saba 'tail' (table 4.3), exhibits extensive syncretism. The difference between morphological forms is compared to their main function as cases of nominal arguments in the tables.

Both the nominative and partitive occur as cases of subject and object. The difference is that the nominative is primarily the case of subject and may occur as the case of object only under restricted conditions. The partitive is primarily the case of object and may occur as the case of subject only under restricted 


\section{MORPHOLOGICAL CHANGE AND THE INFLUENCE OF LANGUAGE CONTACTS IN ESTONIAN}

conditions. Clause semantic rules strictly command upon a seemingly chaotic functional division of grammatical cases so that, as a rule, the nominative is labelled as the case of subject while genitive(-accusative) and partitive are the cases of object. The semantic interpretation of a nominal argument is based on the syntactic position of the constituent and its morphological form.

In table 4.1 the inflection of vaene 'poor' presents the maximal morphological distinction between the grammatical cases. The difference of the nominative and genitive is based on stem alternation whereas other cases have a suffixal marker. In this sort of paradigms that completely avoid syncretism there is no risk of overlapping between the form of the nominal core arguments.

\begin{tabular}{|c||c|c||c|c|}
\hline \multirow{2}{*}{\multicolumn{1}{|c||}{ 'poor' }} & \multicolumn{2}{c||}{ form } & \multicolumn{2}{c|}{ function } \\
\cline { 2 - 5 } & paradigm & syncretism & distinctive & overlapping \\
\hline \hline NOM & vaene & - & subject / object & - \\
\hline GEN & vaese & - & attribute / object & - \\
\hline PART & vaes- $t$ & - & object / subject & - \\
\hline ILL & vaese-sse & - & adverbial (spatial) & - \\
\hline
\end{tabular}

Table 4.1. The declension of nouns that make the maximal distinction between grammatical cases by means of suffixes and flexion.

15 The second example of morphological distinction between grammatical cases and the paradigm of kott 'bag' displays exclusively flexive forms. Historically, this paradigm indicates that the distinction between inflectional categories can completely shift from suffixal morphology to flexion without breaking up the opposition between cases. As mentioned, the historical genitive $-n$ was

20 completely lost in Estonian, and this word type does not display a suffixal descendant of the historical partitive $*-t A$, either. Nevertheless, there is paradigmatic homonymy between the partitive and illative cases, because the form kotti represents both of them. Yet, this kind of syncretism does not cause overlapping of functions, because the grammatical role depends on valency and obligatoriness of constituents. 
RIHO GRÜNTHAL

\begin{tabular}{|c||c|c||c|c|}
\hline \multirow{2}{*}{ 'bag' } & \multicolumn{2}{c||}{ form } & \multicolumn{2}{c|}{ function } \\
\cline { 2 - 5 } & paradigm & syncretism & distinctive & overlapping \\
\hline NOM & kott & - & subject, object & - \\
\hline GEN & koti & - & attribute, object & - \\
\hline PART & kotti & + & object, subject & - \\
\hline ILL & kotisse $\sim$ kotti & $(+)$ & $\begin{array}{c}\text { adverbial } \\
\text { (spatial) }\end{array}$ & - \\
\hline
\end{tabular}

Table 4.2. The declension of nouns that make the maximal distinction between grammatical cases by means of flexion and may display syncretism between the partitive and illative.

5 The third alternative is illustrated in table 4.3. in which the distinction between the three grammatical cases is completely interefered by syncretism. In table 3 (see above) it was pointed out that actually the linearity of syncretism depends on the fonological structure of the word. Syncretism between the nominative, genitive and partitive represents the most extreme type. This paradigm affects the form of subject and object and actually deletes the distinction between various forms of object. Furthermore, such two-syllable words that have a vowel ending in the nominative and do not display consonant gradation nor any other kind of stem alternation, cannot distinguish between the three first cases of the paradigm.

15

\begin{tabular}{|c||c|c||c|c|}
\hline \multirow{2}{*}{ 'tail' } & \multicolumn{2}{c||}{ form } & \multicolumn{2}{c|}{ function } \\
\cline { 2 - 5 } & paradigm & syncretism & distinctive & overlapping \\
\hline \hline NOM & saba & + & & subject, object \\
\hline GEN & saba & + & attribute & object \\
\hline PART & saba & + & object, subject \\
\hline ILL & $\begin{array}{c}\text { sappa } ~ \\
\text { sabasse }\end{array}$ & - & $\begin{array}{c}\text { adverbial } \\
\text { (spatial) }\end{array}$ & - \\
\hline
\end{tabular}

Table 4.3. The declension of nouns that fail to make a distinction between (two or more) grammatical cases and results in an extensive syncretism.

The inflection of saba 'tail' and the same kind of nouns suggests that there must be alternative ways of compensating the inflectional handicap and identical forms (Harris\&Campbell 1995:317-325). Some Indo-European languages, for instance, have compensated morphological merger with increased use of prepositions (Luraghi 1987). Morphologically, the asymmetry between the paradigm as illustrated in table 4.3 and the others (cf. paradigms 
in tables 4.1 and 4.2) consists of several elements. Firstly, flexion fails to compensate the reduction of suffixal inflection. Secondly, the variation of allomorphs affects the partitive and illative which makes the paradigms unpredictable to a certain degree. Thirdly, the mixed morphological strategies of the grammatical cases and allomorphism decrease the uniformity of paradigms.

Blevins (2005:2) claims that property-form mismatches in Estonian declensional system are symptoms of a more general problem, because there is no morphological correspondence between these units. He also notes that inflectional forms cannot be used regressively to reproduce the properties of a noun.

10 This adds evidence on the viewpoint that the rules of Estonian case morphology are lexeme-based.

Table 4.3. demonstrated the way in which syncretic forms affect subject and object. Thus, transitive clause is the context in which the realization and functional consequence of syncretism will have to be examined. Some reports 15 (Erelt\&Metslang 1997) have already pointed out changes taking place in Estonian transitive clause. However, given that the current article merely seeks to point out the sources of grammatical change in Estonian, the transitive clause will not be dealt with in more detail in this occasion.

Conclusively, Estonian case system reflects a sort of intermediate state

20 between historical changes and a morphologically more uniform organization of the paradigm of grammatical cases. Case syncretism plays a significant role in the synchronic relationship between different categories and strongly influences the cases of subject and object. Historically, the strong reduction of suffixal elements was crucial for the rise of identical forms in certain para25 digms. The next section will therefore discuss the role of syncretism in some other Finnic languages and those morphological changes that would potentially support the assumption that it may trigger subsequent changes.

\section{Syncretism of grammatical cases in other Finnic languages}

There are two significant morphological, although chronologically clearly distinct changes that affect the Estonian case system. The merger of the Uralic proto-language genitive $(*-n)$ and accusative $(*-m)$ is shared by all Finnic

35 languages, most Saami languages and Mordvin. This change resulted in a syncretic genitive(-accusative) case. Grammars of individual Finnic languages, such as the largest existing Estonian (Erelt \& al. 1993-1995) and Finnish (Ha- 


\section{RIHO GRÜNTHAL}

kulinen \& al. 2004) academic grammars, mainly present the genitive(-accusative) as (morphologically) one multifunctional and historically dyadic but not syncretic form.

Several millennia later, a subsequent change followed the historical merger

5 of the genitive and accusative. The loss of the genitive(-accusative) - $n$ happened in Livonian, Estonian, Vote as well as south-western and southeastern Finnish dialects. The merger of the genitive(-accusative) must naturally be considered as older and dated to an early proto-language stage that preceded the Proto-Finnic era (Bartens 1999:91-92, Korhonen 1981:212-214,

10 Sammallahti 1998:65-66), while the loss of the genitive $-n$ happened in Estonian only at the end of the Middle Ages (Kingisepp \& al. 1997:87-89, Rätsep 1989:1514-1515). Due to a relatively late periodisation of the loss of the genitive(-accusative) $-n$ it is most logical to assume convergence in those closely related languages and dialects in which it occurred.

The synchronic case paradigms of Livonian, Estonian, Vote and southwestern Finnish dialects demonstrate different ways of adapting the case system to those changes that were caused by phonological loss of the suffix. The evidence in this section is drawn from south-western Finnish dialects, and Vote language that was spoken in Ingria on the south-eastern coast of the Gulf of Finland. Livonian exhibits a considerably simplified case paradigm and a complete syncretism between the genitive(-accusative) and nominative in the plural. The distinction between singular forms depends on the declension type and was lost in many paradigms as well.

The point is that those morphological changes that happened in southwestern Finnish and Vote influenced the same cases as in Estonian. The singular nominative, genitive(-accusative), partitive and illative forms indicate the dynamics of change in the case system as an inflectional paradigm. Paunonen (2003) demonstrated the similarities between the case system of southwestern Finnish dialects and Estonian. The declension table shows the same morphological characteristics as Standard Estonian, namely the extension of flexive forms of those stem types that used to display morphophonological stem alternation (cf. the words lumi 'snow', käsi 'hand' and ranta 'shore' in table 5.1.), and the overlapping of case forms. Syncretism affects most of all certain two-syllable vowel-ending nouns that did not display any morphophonological alternation (cf. the words kala 'fish' and lasi 'glas' in table 5.1. with the inflection of Estonian nouns in tables 4.1-4.3). 
MORPHOLOGICAL CHANGE AND THE INFLUENCE OF LANGUAGE CONTACTS IN ESTONIAN

\begin{tabular}{|c||c|c|c|c|c|}
\hline & 'fish' & 'glas' & 'snow' & 'hand' & 'shore' \\
\hline \hline NOM & kala & lasi & lumi & käsi & ranta \\
\hline GEN & kala & lasi & lume & käre & ranna \\
\hline PART & kala & lasi & lun-t & kät & rant-ta \\
\hline
\end{tabular}

Table 5.1. The inflection of grammatical cases (singular) in south-western Finnish dialects (Paunonen 2003:220).

Table 5.2. demonstrates the declension of the same nouns in Estonian. Note 5 that kala, lumi and käsi are cognate words in Finnish and Estonian with shared prehistoric roots and descend from the earliest known (Uralic) proto-language, while Finnish ranta, Estonian rand is an old Germanic loanword. Finnish lasi (in some dialects klasi) was borrowed from Swedish, whereas Estonian klaas was borrowed from German (Hinderling:182, Itkonen\&Kulonen 1992-

10 2000:2:49, 3:48, Mägiste 1982-83:861, 2409-2410).

\begin{tabular}{|c||c|c|c|c|c|}
\hline & 'fish' & 'glas' & 'snow' & 'hand' & 'shore' \\
\hline \hline NOM & kala & klaas & lumi & käsi & rand \\
\hline GEN & kala & klaasi & lume & käe & ranna \\
\hline PART & kala & klaasi & lun-d & kätt & ran-da \\
\hline
\end{tabular}

Table 5.2. The inflection of Estonian words corresponding to those of table 5.1.

The fourth case that is involved with syncretism in south-western Finnish dialects is the illative. Paunonen (2003:218) provides three allomorphs of the illative that occur in different areas of south-western Finnish dialects. The first of them kala fish.ILL extends the syncretism to four cases, the second kala-sse fish-ILL exhibits a similar analogical illative as Estonian, while the third kala$h a$ fish-ILL (in the northern part of the dialect area) descends from the old suffix that was lost elsewhere.

20 The difference in the development of Vote language is that word-final elements were generally maintained. Thus, unlike Estonian, Livonian and south-western Finnish dialects no systematic apocope took place in Vote. However, the loss of the genitive $-n$ and the attrition and loss of the partitive and illative suffix in certain frequent declension types caused a similar morphological dichotomy between syncretic flexive forms and distinct agglutinative cases as in Estonian and south-western Finnish dialects. Table 5.3. demonstrates two inflectional paradigms of the grammatical cases and the 


\section{RIHO GRÜNTHAL}

illative of two Vote nouns. The inessive forms illustrates the inflections adverbial cases that, in general, display suffixal morphology as adverbial cases in Estonian do (cf. table 2. above).

\begin{tabular}{|c||c|c|}
\hline & 'sauna' & 'cross' \\
\hline \hline NOM & sauna & rissi \\
\hline GEN & saunaa & risii \\
\hline PART & saunaa & rissi-ä \\
\hline ILL & saunaa & rissii \\
\hline INESS & sauna-za & rissi-zä \\
\hline
\end{tabular}

Table 5.3. The inflection of Vote sauna 'sauna' and rissi 'cross'.

The influence of syncretism in Vote is basically the same as in Estonian and south-western Finnish dialects. Analogical agglutinative forms became allomorphs of the illative, but in addition to it, analogical agglutinative partitive forms are characteristic of Vote (Ariste 1968:43-53, Markus 2006:94-95).

10 Nevertheless, the change was not completely finished by the time 20-century records on Vote were made. Analogical forms did not always replace the syncretic forms, if, for instance, the distinction between semantic roles is based on the semantic structure of the clause. This is illustratively seen in the following three examples that are drawn from the text collection of Ariste (1974). In example (1) the syncretic form saunaa is the object of the clause and an obligatory constituent of the transitive clause. Note that in this section the overlapping between the genitive(-accusative), partitive and illative in words like sauna in Vote, syncretic forms should actually be glossed GEN-ACC-PARTILL to illustrate all possible morphosyntactic properties of one particular form.

20 However, we have preferred to sign those forms with an asterisk * instead of a too complicated notation.

\section{(1) A saunaa * mussaa vït-tä lämmitä-tti-i. but sauna.PART black.PART way-PART warm-PASS-IMPF}

'But the sauna was warmed as a chimneyless sauna.' (Ariste 1974:10)

In example (2) the verb süntüä 'be born' is intransitive. Consequently, the intransitivity of the verb is a constraint due to which the syncretic form saunaa cannot be any of the two cases, i.e. the genitive-accusative nor the partitive, that occur as the case of object of an affirmative declarative clause. 


\title{
MORPHOLOGICAL CHANGE AND THE INFLUENCE OF LANGUAGE CONTACTS IN
}

ESTONIAN

\author{
(2) Lahzõ-t süntü-zi-vät sauna*. \\ children-PL bore-IMPF-PL3 sauna.ILL \\ 'The children were born in the sauna.' (Ariste 1974:10)
}

Thus, valency is decisive for the decoding of syncretic forms in examples (1) and (2). A syntactic test is actually very illustrative with respect to the

5 functional burden of syncretic forms. In Estonian there are several syntactic means that actually eliminate the influence of paradigmatic syncretism. Agreement between an adjective attribute and noun, a passive or negative form of the verb frequently reveals the exact category paradigmatically overlapping forms (Grünthal 2001). The risk of running into semantic ambiguity is 10 essentially decreased this way. However, Vote provides an illustrative example of the gradual re-establishing of a morphological distinction between syncretic forms. The same informant that used the syncretic illative form saunaa in example (2) applies the analogical suffixal illative saunaa-sõ $\tilde{o}$ in the same story (example 3).
(3) Lumi läpi seinää* kõik saunaa-sõ̃o tuiska-z. snow through wall.GEN-ACC all sauna-ILL whirl-IMPF
'The snow whirled into the sauna through the wall.' (Ariste 1974:10)

The verb tuiskaz 'whirled' is intransitive as the verb in example (2) is. There are two adverbial constructions and the first of them läpi seinää 'through the wall' is a prepositional phrase that includes a noun seinää (the nominative form

20 is seinä) that morphologically could be either genitive-accusative, partitive or partitive (cf. the declension of sauna in table 5.3.). Although there is no structural item that would trigger the analogical illative of saunaa-sõo, the informant has chosen to display it instead of the short allomorph.

The semantic structure of the clause and the transitivity or intransivity of 25 the verb are crucial for the decoding of the morphosyntactic information of syncretic forms. While the nominal complement of a transitive verb displays one of the object cases (the genitive-accusative or the partitive; example (1), the complement of an intransitive verb exhibits an adverbial case (example 2). Thus, in the illustrated context the verb construction draws a line between 30 overlapping forms. However, as demonstrated in (4a-b), this is not always the 


\section{RIHO GRÜNTHAL}

case and an elliptic clause may trigger a grammatical disorder that is caused by the syncretism.
(4a)
Naizikko ôli
sauna-za
päiväa*
ühesää*.
woman was
sauna-INESS
day.PART
nine
Naizõ-t
tšăü-tii
vaatta-ma-a. - -
woman-PL
visit-PASS.IMPF look-INF-ILL
(4b) Ühsinää
eb jäte-ttü
$\dddot{o O}-s s i$
saunaa*.
alone
not leave-PASS.PTCP.PST
night-TRANSL sauna.ILL

'The woman spent nine days in the sauna. (Other) woman went to see her. - -

(The woman) was not left alone in the sauna overnight.' (Ariste 1974:11)

Kommentar [BiHo: added the , h', was that right?
5

The verb denoting 'leave (somebody or something)' is transitive and the negative clause $e b$ jätettü triggers a partitive form of the object. Nevertheless, the noun saunaa that is in the partitive form is not the object in this particular case but an adverbial complement. The topic of the given text sample is naizikko 'woman' (example 4a) and it is semantically embedded without marking it overtly in the form of a pronoun or noun in (example $4 b$ ).

Consequently, there are several subtle and frequently invisible grammatical means of disambiguating the functional burden of paradigmatic overlappings. Examples (5) and (6) illustrate the importance of all constituents for the 15 analysing of the semantic roles of syncretic forms. In example (5) the same form saunaa that was illustrated above in examples (1), (2) and (4b) is at the position of genitive-attribute that precedes the head ahjoosõo (5). The position of a genitive attribute reveals the morphological form of the word and excludes the possibility of being decoded as the partitive as a case of object 
MORPHOLOGICAL CHANGE AND THE INFLUENCE OF LANGUAGE CONTACTS IN

ESTONIAN

(5)

$\begin{array}{llll}\text { Oomnizõo } & \text { tulla-z, } & a \text { emä } & \text { on pise-ttü } \\ \text { morning.ADESS } & \text { come-PASS } & \text { but mother is put-PASS.PTCP.PST } \\ \text { kahzii } & \text { kôrroo } & \text { saunaa }^{*} & \text { ahjoo-sỗo. } \\ \text { two.INSTR } & \text { turn.INSTR } & \text { sauna.GEN(-ACC) } & \text { oven-ILL }\end{array}$

'They arrive in the morning but the mother has been folded double in the oven of the sauna.' (Ariste 1974:11)

In example (5) the attribute phrase saunaa ahjoosõ is an adverbial complement. In example (6) the attribute phrase saunaa naissa is submitted to transitive verb vaattamaa and is the object of the verb phrase.

$\begin{array}{llll}\text { (6) Juôl-ti-i: } & \text { mee-mmä vaatta-maa } & \text { saunaa } & \text { naissa! } \\ \text { talk-PASS-IMPF go-PL1 look-INF.ILL sauna.GEN(-ACC) } & \text { woman.PART }\end{array}$

'They said that they will go and see the woman of the sauna.' (Ariste 1974:13)

The decoding of saunaa as a genitive attribute in example (6) is based solely on its pre-nominal position. This obviously eliminates the possibility to decode saunaa as an adverbial constituent of the clause. Furthermore, if saunaa would be an adverbial constituent in example (6), there would be an additional need to mark the adverbial form with an analogical suffix as in example (3) above.

Conclusively, paradigmatic overlapping of cases affects at least in certain declension types also other Finnic languages than Estonian. The compensation

15 of this handicap is sometimes visible in inflectional paradigms in the extension of morphological strategies or productive agglutinative forms as in the case of south-western Finnish dialects and Vote. However, the compensation does not always take place only by morphological means but syntactic and semantic structure. This sort of evidence suggests that syncretism actually shows to the 20 importance of syntactic means in distinguishing between grammatical relations. Accordingly, the next sections set out of this claim and seek to point out some relevant characteristics in contact-induced changes in Estonian. 


\section{RIHO GRÜNTHAL}

\section{Language contacts and Estonian literary language}

The influence of German language and its varieties such as Middle Low German is most illustratively seen in Estonian vocabulary and intensive lexical borrowing. The foundation and early development of literary Estonian took place under foreign interference, and German-speaking priests actively applied the language of local people in service. A vast majority of the authors of early Estonian texts and translations were Germans. This sort of non-native-speaker language cultivation was significant from the 16th to 18th century. Although there is little evidence, that bilingualism would have been wide-spread during the whole contact period, this sort of literary bilingualism undoubtedly influenced the development of literary Estonian (cf. Ariste 1940a, 1940b, 1963, 1981, Hinderling 1981).

It is frequently assumed that the influence of German increased analytical constructions and decreased syntheticity in Estonian. The most concrete evidence is found in the research of Cornelius Hasselblatt who points out that $60 \%$ of Standard Estonian phrasal verbs (prefixal verbs) have a more or less identical semantically and functionally uniform equivalent in German (Hasselblatt 1990:205). The rise and diffusion of phrasal verbs in Estonian is not limited in lexically corresponding constructions only but the general extension of the construction type. A particularly productive unit is ära 'away' that is not bound to any semantic verb category, a semantically abstract free morpheme that is more flexibly attached to verb phrases than other particles such as ette 'in front of', läbi 'through', sisse 'in', välja 'out(side of)' etc. that are used as adverbs in phrasal verbs but are frequently used as adpositions as well. The diffusion of ära is seen in Old Literary Estonian in which ära was more regularly used as a marker of perfectivity than in modern EE. In the data that originates from the 16th and the following centuries Estonian verbs with the complement ära functionally corresponds to several German verb prefixes such as ab-aus-, be-, davon-, ent-, er-, fort-, hinweg-, ver-, weg-, zer-(Metslang 2001:455).

The high number of corresponding phrasal verbs between Standard Estonian and German is illustrated in the next examples that are drawn from the internet. The corresponding pairs are Estonian välja ehitada [out] 'build', German ausbauen [out] 'build' id. in example (7) and Estonian läbi mängida [through] 'play', German durchspielen [through] 'play' in example (8). In example (9) there is another Estonian phrasal verb üles ütlema 'quit, cancel', 


\section{MORPHOLOGICAL CHANGE AND THE INFLUENCE OF LANGUAGE CONTACTS IN}

ESTONIAN

literally '[up] say' (German 'versagen' ['aufsagen']), that does not correspond to a German word one-to-one but, yet, has a complete parallel in German absagen away say, or aussagen out say.

$\begin{array}{lllll}\text { (7) } & \text { Seal } \text { oli vaja } & \text { välja ehita-da lisa-ks } \\ \text { there } & \text { was must } & \text { out build-INF } & \text { more-TRANSL } \\ \text { kaks } & \text { suur-t } & \text { ringi. } & \\ \text { two } & \text { big-PART } & \text { circle.PART } & \end{array}$

'In addition to that it was necessary to build two big circles there.'

(8) kõikole-ks kõigi-ga korra läbi mängi-nud.

all is-COND all-COM once.GEN-ACC through play-PTCP

'Everyone would have played once with everyone.'

(9) Arvuti [on] vist ütle-nud üles.

Computer [is] maybe say-PTCP.PST up

'The computer was probably broken.'

In the most transparent cases such as examples (7) and (8) the language contact source can be detected on lexical evidence, while in example (9) the 10 assumption of a semantic borrowing is based on the syntactic and semantic relationship between the verb and the complement. So, Estonian phrasal verb constructions pretend as grammatical replication to the model language that is German. In all three illustrated examples the dependence between two constituents is construction-specific and lexically motivated due to which the

15 adverb of a phrasal verb at issue cannot be randomly attached to any other word. In other words, those adverbs of phrasal verbs that are not freely transmissible units are parts of lexical constructions and not diffusive grammatical entities.

The most productive adverb that is used in phrasal verbs and clearly 20 exhibits other than lexically conditioned properties is ära. Its basic meaning as a free word is 'away'. The main difference with respect to other adverbs of phrasal verbs is that, as a rule, its occurrence in a sentence is not lexically but syntactically conditioned. Metslang (2001:446-451) concludes that some verbs may obligatorily demand the particle ära with the total object. Some 


\section{RIHO GRÜNTHAL}

verbs use ära as an optional double marker of perfectivity. And finally, some verbs use ära occasionally as a perfective marker. Thus, verbal and clausal semantics are crucial for the occurrence of ära. Whether ära is used in a particular constructions therefore depends on the degree of transitivity and aspect of the verb. Although transitivity is one of those features that may demand the use of ära (examples 10-12), it also occurs in intransitive sentences (example 13).

(10) Tartu jäta-b ära aastavahetuse-ks planeeri-tud

Tartu leave-SG3 away turn-of-the-year-TRANSL plan-PASS.PTCP.PST

ilutulestiku.

fireworks.GEN-ACC

'Tartu lets the fireworks be that were planned for the turn of the year.'

(11) Kuidas uudis-t ära tun-da?

How news-PART away know-INF

'How to recognize a piece of news?'

10

(12) Ol-ge mure-ta me osta-me selle Tei-lt ära! be-IMP.SG2 worry-ABESS we buy-PL1 it.GEN-ACC you-ABL away

'Never mind, we shall buy it from you!'

In examples (10-12) the finite verb of each sentence is transitive, namely jätta 'leave', tunda 'know' and osta 'buy'. In two of them the object, ilutulestiku in (10) and selle in (12), is in the genitive-accusative that indicates high transitivity, while in (11) the object uudist formally is in the partitive case that indicates lower transitivity. In this particular case a genitive-accusative form of the object uudise would not be possible. Moreover the clausal semantics emphasise the momentanous character of the process and, hence, a perfective aspect. Yet, the partitive form of the object, the decrease of transitivity and

20 imperfective aspect do not exclude the occurrence of a phrasal verb as example (13) with a partitive object pileteid 'tickets' and a pronominal nominative object nad 'they' confirms. 
MORPHOLOGICAL CHANGE AND THE INFLUENCE OF LANGUAGE CONTACTS IN

ESTONIAN

$\begin{array}{lllll}\text { (13) Aeg muudkui } & \text { lähe-bja } & \text { keegi } & \text { pole veel } \\ \text { time just } & \text { go-SG3 and nobody } & \text { is.NEG } & \text { yet } \\ \text { pilete-i-d } & \text { ära } & \text { ost-nud, } & \text { aga } & \text { taha-ks } \\ \text { ticket-PL-PART } & \text { away } & \text { buy-PTCP.PST } & \text { but } & \text { want-COND } \\ \text { ikka nad } & \text { ära } & \text { müü-a. } & & \\ \text { always they } & \text { away } & \text { sell-INF } & & \end{array}$

'The time just keeps going and nobody has not bought the tickects yet, but [I] would still want to sell them.'

In example (14) the verb pôleda 'burn' is intransitive (note that the transitive form póletada is a derivation of the same stem) and ära is the marker of 5 perfective aspect.
(14) Nädalavahetuse-1 toimu-nud Pihkva ralli-1 weekend-ADESS happen-PTCP.PST Pskov.GEN-ACC ralley-ADESS põle-s ära üks sõiduk. burn-IMPF away one vehicule
'A car burned down at Pskov ralley that was held at the weekend.'

In conclusion, ära is commonly used to mark especially two grammatical properties, namely transitivity and perfective aspect. (For more examples and 10 a more detailed description of the problem, see Metslang 2001.) The question that ultimately emerges from the intensive diffusion of ära is whether there are parallel grammatical changes that are related with the role of phrasal verbs. The intensive erosion of grammatical cases and suffixal morphology that was discussed above in more detail are the basis of the assumption of mutual 15 dependence between various changes. Although the loss of individual suffixes and merger between grammatical cases was not caused by foreign interference, it is indispensable to find out the core properties that were under the influence of individual changes and briefly analyse their mutual compatibility. 


\section{RIHO GRÜNTHAL}

\section{The compatibility of morphological and contact-induced change}

Functional take-over and compensating of an eroding or lost category has been reported to take place by morphological, syntactic reorganising of language structure, and eventually under the influence of language contact (Heine \& Kuteva 2005:124, 141-143). The evidence of Estonian and other Finnic languages suggests that, in general, it appears that if the morphology of a given language is affected by the attrition of let us say suffixes, there are probably several parallel changes that affect the system. A causal interliaison may well be assumed, if there is a functional overlapping between individual constructions and grammatical categories. This does not implicate that any change that happens is caused by a preceding one. The current analysis of morphological change and language contacts in Estonian seeks to point out the intertwining between morphological attrition, syntactic change and language contacts.

The examples (10-12) above demonstrated that Estonian phrasal verb constructions are used in transitive clauses, in which the case of the object is not always the same. In the beginning of this article it was claimed that syncretism between the cases of object and the potential overlapping of the form of subject and object are a possible reason for morphosyntactic changes. The role of phrasal verbs in turn is most salient in aspect marking constructions (Metslang 2001) and aspect is the most important synchronic property of phrasal verbs.

Example (15) presents a context in which the case of object is not morphologically marked, due to which the aspect of the aspect of the clause would be undefined, if the adverb ära would not occur as an aspect marking particle. The nominative and genitive(-accusative) form of the noun mure are identical and the same is valid to the possessive attribute oma 'own' that displays syncretism between the nominative, genitive(-accusative) and partitive. In example (15) there is no evidence on the form of oma word except that as an adjective attribute it should agree in case with the head. However, as mentioned, the morphological form of the head mure is ambiguous as well. Consequently, the syncretism affects the case of object and, hence, the transitivity and aspect of the clause. In this particular case the adverb ära marks the perfective aspect of the predicate kirjutasin 'I wrote'. 
MORPHOLOGICAL CHANGE AND THE INFLUENCE OF LANGUAGE CONTACTS IN

ESTONIAN

(15) Kirjuta-si-n seepeale write-IMPF-SG1 after vist foto.kala.ee foorumi-sse

oma mure maybe [foto.kala.ee] forum-ILL

own worry.GEN-ACC away

'After it I wrote my concern to the forum "foto.kala.ee".'

As Metslang (2001) points out, the occurrence or lack of the phrasal verb is illustratively seen in simple transitive clauses, in which both the verb and the genitive(-accusative) form of the object indicate the restrictedness of the object and the perfective aspect. In the last examples the Estonian transitive clauses (16) are contrasted with corresponding Finnish ones (17) that in both cases lack the phrasal adverb.

(16a) Tüdruk sõi leiva ära.

girl ate bread.GEN-ACC away

'The girl ate the bread.'

10

(16b) Tüdruk sõi leiba.

girl ate bread.PART

'The girl was eating the bread.'

(17a) Tyttö söi leivän.

girl ate bread-GEN-ACC

'The girl ate the bread.'

(17b) Tyttö söi leipää.

girl ate bread-PART

'The girl was eating the bread.'

The difference of example (16a) that displays a genitive-accusative object leiva 15 with respect to the three other ones is that this is the only context in which a phrasal verb occurs. The phrasal verb is less likely to occur in a transitive clause in Estonian, if the object is in the partitive. Finnish that has preserved 


\section{RIHO GRÜNTHAL}

suffixal marking of grammatical cases does not display phrasal verbs like Estonian. Given that the combinations of verbs and adverbs in phrasal verbs are lexically conditioned it would be too simple to conclude that the loss of genitive(-accusative) $-n$ caused the emergence of the category of phrasal verbs.

5 Yet, although the functional properties of the cases of object and phrasal verbs do not match one-to-one, the latter ones are used as syntactic compensation of the preceding morphological change.

As Metslang (2001:475) concludes, the rise and extension of phrasal verbs in Estonian is a result of the cumulation of various changes. The relationship

10 between morphological attrition and new syntactic constructions is not implicational, because the first one does not trigger the latter one. Otherwise one would expect to find productive phrasal verbs in languages such as south western Finnish dialects and Vote that are influenced by a similar overlapping of crucial forms and syncretism between cases that mark nominal core 15 arguments. However, the morphological attrition and the strong increase of syncretism were an important precondition for subsequent compensating changes. The relative chronology of those phenomena that were discussed in this article suggests that the order of the changes is significant. It is summarised in figure 1. 


\section{MORPHOLOGICAL CHANGE AND THE INFLUENCE OF LANGUAGE CONTACTS IN \\ ESTONIAN}

5

- the loss of word-

final (gen-acc) $-n$

took place in the 15 th

and 16 th century

- erosion of suffixal mor-

phemes and paradigmatic

overlapping between

grammatical cases (NOM /

GEN-ACC / PART) caused

syncretism

10 - case syncretism blurred the relationship between semantic roles and increased morphosyntactic ambiguity

15

- language contacts reinforced the emergence of phrasal verbs as a compensating syntactic pattern

20

25

- lexically conditioned phrasal verbs and the verb particle ära in particular are frequently used to indicate the aspect of the clause

30 Figure 1. The relative chronology of morphological erosion of grammatical cases, syncretism and emergence of phrasal verbs in Estonian.

The main point of the relative chronology of the listed grammatical phenomena and diachronic changes is that the order between the loss of suffixal

35 elements and compensating changes is clear. There is no reason to assume that the order would have been vice versa and the phonological loss of word-final $-n$ would have been triggered by the rise of the category of phrasal verbs. Chronologically, the beginning of areal contacts between Estonian and 


\section{RIHO GRÜNTHAL}

German precede the assumed periodisation of the loss of the genitive(accusative) $-n$, because the German crusaders invaded the Baltic countries already in the beginning of $13^{\text {th }}$ century. However, the evidence of phrasal verbs suggests that the influence of German in this particular category took place more intensively only since the $16^{\text {th }}$ century as literary use of Estonian gradually gained more space.

\section{Department of Finno-Ugrian Studies}

Alvre, Paul 1964. 'A-mitmuse päritolust'. Emakeele Seltsi Aastaraamat 10:57-80.

Alvre, Paul 1989. Eesti kirja- ja murdekeele morfoloogiat. Tallinn: Valgus.

Ariste, Paul 1940a. Saksa laensõnadest 16. sajandi eesti kirjakeeles. Eesti Keel 19:108-112.

Ariste, Paul 1940b. Georg Mülleri saksa laensõnad. Acta et Commentationes Universitatis Tartuensis B 46:1.

Ariste, P. 1963. Saksa laensõnad Heinrich Stahli eesti keeles. Emakeele Seltsi Aastaraamat 9:85-119.

Ariste, P. 1968. Grammar of Votic language. Bloomington: Indiana University publications.

Ariste, P. 1974. Vadjalane kätkist kalmuni. Tallinn: Eesti NSV Teaduste Akadeemia.

Ariste, P. 1981. Keelekontaktid. Eesti keele kontakte teiste keeltega.Tallinn: Valgus.

Bartens, R. 1999. Mordvalaiskielten rakenne ja kehitys. Helsinki: Finno-Ugrian Society.

Blevins, J. P. 2004. 'Inflection Classes and Economy'. In: L. Gunkel, G. Müller \& G. Zinfonun (eds.), Explorations in Nominal Inflection. Berlin: Mouton de Gruyter, 41-85.

Blevins, J. 2005. 'Word-based declension in Estonian'. In: G. Booij \& J. van Marle (eds.), Yearbook of Morphology 2005. Amsterdam: Springer. Pp. 1-25.

Carstairs, A. 1984. 'Outlines of a constraint on syncretism'. In: Folia Linguistica 18:73-85

Carstairs, A. 1987. Allomorphy in inflexion. London: Croom Helm Linguistics series. 


\section{MORPHOLOGICAL CHANGE AND THE INFLUENCE OF LANGUAGE CONTACTS IN}

ESTONIAN

Coleman, R. 1976. 'Patterns of Syncretism in Latin'. In: A. M. Davies \& W. Meid (eds.), Studies in Greek, Italic and Indo-European Linguistics Offered to Leonard R. Palmer. Innsbruck: Institut für Sprachwissenschaft der Universität Innsbruck. 47-56

5 Delbrück, B. 1907. Synkretismus: ein Beitrag zur germanischen Kasuslehre, Strassburg: Trübner.

Ehala, M. 1997. 'Eesti morfoloogia olemus'. Keel ja Kirjandus 40:370-383.

Erelt, M., R. Kasik, H. Metslang, H. Rajandi, K. Ross, H. Saari, K. Tael \& S. Vare 1993-1995. Eesti keele grammatika I-II. Tallinn: Eesti Teaduste Akadeemia.

10 Erelt, M., T. Erelt \& K. Ross 1997. Eesti keele käsiraamat. Eesti Keele Sihtasutus. Tallinn.

Erelt, M. \& H. Metslang 1997. Oma või võõras? („Muutuv keel“). Keel ja Kirjandus 40:657-668.

Grünthal, R. 2000. 'Typological characteristics of the Finnic languages: a reappraisal'. In: J. Laakso (ed.), 31-63.

Grünthal, R. 2001. 'Homonymy and systemacy in Estonian inflection'. In: R. Kasik (ed.), Keele kannul. Pühendusteos Mati Erelti 60. sünnipäevaks. Tartu: University of Tartu. 42-61.

Grünthal, R. 2002. 'Vormihomonüümia ja muutuv keel'. In: R. Kasik (ed.), Lähivertailuja 12. Soome-eesti kontrastiivseminar 30.5.-1.6.2001 Kääriku. Tartu: University of Tartu. 21-34.

Grünthal, R. 2003. Finnic Adpositions and Cases in Change. Helsinki: Finno-Ugrian Society.

Habicht, K. 2000. 'Grammaticalization of Adpositions in Old Literary Estonian'. In: Mati Erelt (ed.), Estonian Typological Studies IV. Tartu: University of Tartu. 1958.

Hakulinen A., M. Vilkuna, R. Korhonen, V. Koivisto, T.R. Heinonen \& I. Alho 2004. Iso suomen kielioppi. Helsinki: Suomalaisen Kirjallisuuden Seura.

Harris, A. C. \& L. Campbell 1995. Historical syntax in cross-linguistic perspective. Cambridge: Cambridge University Press.

Hasselblatt, C. 1990. Das estnische Partikeladverb als Lehnübersetzung aus dem deutschen. Veröffentlichungen der Societas Uralo-Altaica 31. Wiesbaden: Harrassowitz.

Hasselblatt, C. 2003. 'Nochmals zur "typologischen Plausibilität" der Partikelverben im Uralischen'. In: Bakró-Nagy, M. \& K. Rédei (eds.), Ünnepi könyv Honti László tiszteletére. Budapest: MTA Nyelvtudományi Intézet. 161-171.

Heine, B. \& T. Kuteva 2005. Language Contact and Grammatical Change. Cambridge: Cambridge University Press.

Hennoste, T. 1997. 'Eesti keele sotsioperioodid: üldpilt'. In: M. Erelt, M. Sedrik \& E. Uuspõld (eds.), Pühendusteos Huno Rätsepale 28.12.1997. Tartu: University of Tartu. 45-66.

Hinderling, R. 1981. Die deutsch-estnischen Lehnwortbeziehungen im Rahmen einer europäischen Lehnwortgeographie. Wiesbaden: Harrassowitz. 


\section{RIHO GRÜNTHAL}

Honti，L. 1999. 'Das Alter und die Entstehungsweise der "Verbalpräfixe" in uralischen Sprachen (unter besonderer Berücksichtigung des Ungarischen)'. Linguistica Uralica 35:81-97, 161-176.

Itkonen, E. \& U.-M. Kulonen (eds.) 1992-2000. Suomen sanojen alkuperä 1-3. Etymologinen sanakirja. Helsinki: Suomalaisen Kirjallisuuden Seura.

Johnston, J. 1997. Systematic Homonymy and the Structure of Morphological Categories. Some Lessons from Paradigm. Department of Linguistics University of Sydney. Web address: ses.library.usyd.edu.au/bitstream/2123/396/1/adt-NU1999.0013whole.pdf. Visited in June 2006.

Kettunen, Lauri 1938. Livisches Wörterbuch mit grammatischer Einleitung. Helsinki: Finno-Ugrian Society.

Kettunen, L. 1962 (1929). Eestin kielen äännehistoria. 3. painos. Helsinki: Suomalaisen Kirjallisuuden Seura.

Kingisepp, V.-L., E. Ehasalu, K. Habicht \& J. Peebo 1997. 'Vanimate eesti keele tekstide sõnavarast ja grammatilisest vormistikust'. In: M. Erelt, M. Sedrik \& E. Uuspõld (eds.), Pühendusteos Huno Rätsepale 28.12.1997. Tartu: University of Tartu. 67-100.

Koponen, E. 1998. Eteläviron murteen sanaston alkuperä. Mémoires de la Société Finno-Ougrienne 230. Helsinki: Finno-Ugrian Society.

Korhonen, M. 1981. Johdatus lapin kielen historiaan. Helsinki: Suomalaisen Kirjallisuuden Seura.

Laakso, J. 1998. 'Itämerensuomen ikuisuuskysymyksiä: vielä kerran $a$-monikosta'. In: R. Grünthal \& J. Laakso (eds.), Oekeeta asijoo. Commentationes FennoUgricae in honorem Seppo Suhonen sexagenarii. Helsinki: Finno-Ugrian Society. 268-275.

Laakso, J. 2000a (ed.), Facing Finnic. Some challenges to historical and contact linguistics. Helsinki: Finno-Ugrian Society.

Laakso, J. 2000b. 'Sound history vs. historical grammar: some Finnic examples'. In: J. Laakso (ed.), 113-136.

Laakso, Johanna 2001. 'Native or borrowed, or both - is it possible to have many mothers?' Word 52. 197-212.

Laanekask, H. \& T. Erelt 2003. 'Written Estonian'. In: M. Erelt (ed.), Estonian language. Tallinn: Estonian Academy Publishers. Pp. 273-342.

35 Laanest, A. 1982. Einführung in die ostseefinnischen Sprachen. Hamburg: Helmut Buske Verlag.

Luraghi, S. 1987. 'Patterns of case syncretism in Indo-European languages'. In: A.G. Ramat, O. Carruba \& G. Bernini (eds.), Papers from the Seventh International Conference on Historical Linguistics. Amsterdam: John Benjamins. Pp. 355-371.

Markus, E. B. 2006. Tipologija morfemnogo var'irovanija (na materiale morfologičeskih sistem govorov vodskogo jazyka). Dissertacija na soiskanie učenoj stepeni kandidata filologičeskih nauk. Moskva: Institut jazykoznanija RAN. [Unpublished manuscript.] 


\section{MORPHOLOGICAL CHANGE AND THE INFLUENCE OF LANGUAGE CONTACTS IN ESTONIAN}

Martínez, R. 2001. 'The cognitive base of case syncretism: Conceptual blending of instrumental, comitative, and agent in ancient Greek'. In: Sprachtypologie und Universalienforschung 54:329-345.

Meiser, G. 1992. 'Syncretism in Indo-European languages'. Transactions of the Philological Society 90/2:187-218.

Metslang, Helle 2001. 'On the developments of the Estonian aspect: The verbal particle ära'. In: Dahl, Ö. \& M. Koptjevskaja-Tamm (eds.), Circum- Baltic Languages. Typology and contact 2: Grammar and Typology. Amsterdam: John Benjamins. 443-479.

10 Must, M. 2000. Vene laensõnad eesti murretes. Tallinn: Eesti Keele Sihtasutus.

Mägiste, J. 1962. 'Äldre ryska lånord i estniskan, särskilt i det gamla estniska skriftspråket'. Lunds Universitetets Årsskrift 1:55/1.

Mägiste, Julius 1982-83. Estnisches etymologisches Wörterbuch I-XII. Helsinki: Finno-Ugrian Society. [Unpublished manuscript]

Pajusalu, K. 2000a. 'Alternation of $e$ and $a$, $\ddot{a}$ in non-initial syllables in the southern group of Finnic languages'. In: J. Laakso (ed.), 156-167.

Pajusalu, K. 2000b. 'Eesti keele kujunemisjärgud ja sotsioperioodid'. In: Keel ja Kirjandus 43:153-160.

Paunonen, H. 2003. 'Suomen kielen morfologisista muutosmekanismeista'. In: L. Laitinen et al. (eds.), Muotojen mieli. Kirjoituksia morfologiasta ja variaatiosta. Kieli 15. Helsinki: Helsingin yliopiston suomen kielen laitos. 187-248.

Plank, F. 1991 (ed.). Paradigms. The Economy of Inflection. Empirical Approaches to Language Typology 9. Berlin: Mouton de Gruyter.

Plank, F. 1998. 'The co-variation of phonology with morphology and syntax: A hopeful history'. Linguistic Typology 2:195-230.

Plank, F. 1999. 'Split morphology: How agglutination and flexion mix'. Linguistic Typology 3:279-340.

Rätsep, H. 1989. 'Eesti keele tekkimise lugu'. Akadeemia 1:1503-1524.

Sammallahti, P. 1998. The Saami Languages. An Introduction. Kárášjohka: Davvi Girji.

Skalička, V. 1975. 'Über die Typologie des Estnischen'. Congressus tertius internationalis fennougristarum I. Tallinn. 369-373.

Tauli, V. 1984. 'Is the Structural Change of Languages Really Predestined?' UralAltaische Jahrbücher N.F. 4:25-35.

Tveite, T. 2004. The case of the object in Livonian: A corpus based study. Helsinki: Finno-Ugrian Society.

Werner, O. 1987. 'The aim of morphological change is a good mixture - not a uniform language type'. In: A. G. Ramat, O. Carruba \& G. Bernini (eds.), Papers from the 7th International Conference on Historical Linguistics. Amsterdam: John Benjamins. 591-606.

Viitso, T.-R. 1990. 'Eesti keele kujunemine flekteerivaks keeleks'. Keel ja Kirjandus 33:456-461, 542-548.

Viitso, T.-R. 1998. 'Fennic'. In: Daniel Abondolo (ed.), The Uralic languages. London: Routledge. 96-114.
Kommentar [BiHo10]: I

I've added the ,in“" - is that okay?

Kommentar [BiHo11]:

added - is that okay? 


\section{RIHO GRÜNTHAL}

Viitso, T.-R. 2000. 'Finnic affinity'. In: A. Nurk et al. (eds.), Congressus Nonus Internationalis Fenno-Ugristarum 7.-13.8.2000 Tartu. Pars I. Orationes plenariae \& Orationes publicae. Tartu. 153-178.

Viitso, T.-R. 2003. 'Phonology, Morphology and Word Formation'. M. Erelt (ed.), Estonian Language. Tallinn: Estonian Academy Publishers. 9-92.

Viks, Ü. 1984. ‘Sõnavormide homonüümia eesti keeles'. In: Keel ja Kirjandus 27:97105.

Viks, Ü. 1992. A Concise Morphological Dictionary of Estonian. The Dictionary \& ... added - is that okay? Appendices. Tallinn: Estonian Academy of Sciences. 